\title{
PENGARUH LAMA WAKTU AKTIVASI DAN KONSENTRASI ASAM FOSFAT TERHADAP MUTU ARANG AKTIF KULIT KAYU ACACIA MANGIUM
}

\author{
(The Influence of Activation Time and Concentration of Phosphoric \\ Acid on the Quality of Activated Charcoal of Acacia mangium Bark)
}

\author{
Oleh/By : \\ Gustan Pari $^{1{ }^{1}}$, Djeni Hendra ${ }^{1)}$ \& Ridwan A. Pasaribu ${ }^{1)}$
}

\begin{abstract}
This study was carried out to investigate the influences of activation times and concentrations of chemical activators on the quality and yield of activated charcoal of Acacia mengium Bark. The activated charcoal was produced in a stainless steel retort with electrical heater at the activation temperature of $750^{\circ} \mathrm{C}$ and activation times of 30,60 and 90 minutes, consecutively. Phosphoric acid $\left(\mathrm{H}_{3} \mathrm{PO}_{4}\right)$ was used as an activator agent with the concentrations of $0.0 ; 5,0 ; 10,0$ and $15,0 \%$, consecutively.

The result showed that the optimum condition for producing the best activated charcoal for water purification was obtained with the concentration of $\mathrm{H}_{3} \mathrm{PO}_{4}$ solution of $10.0 \%$, and activation time of 60 minute. This optimum condition produced the activated charcoal yield of $98.20 \%$, containing moisture content of $8.39 \%$, ash content of $26.70 \%$, volatile matter of $8.72 \%$, fixed carbon of $64.60 \%$, iodine adsorptive capacity of $513 \mathrm{mg} / \mathrm{g}$, and benzene adsorptive capacity of $16.10 \%$. Based on the adsorptive capacity of iodine, the activated charcoal from Acacia mangium Bark is good to be used for waterpurification.
\end{abstract}

Keywords: Acacia mangium, wood bark, activated charcoal, fixed carbon, iodine.

\begin{abstract}
ABSTRAK
Dalam tulisan ini dikemukakan hasil penelitian pembuatan arang aktif dari kulit kayu Acacia mangium. Tujuan dari penelitian ini adalah untuk mengetahui pengaruh waktu aktivasi dan konsentrasi bahan pengaktif terhadap hasil dan mutu arang aktif yang dihasilkan. Proses pembuatan arang aktif dilakukan dengan menggunakan retor yang terbuat dari baja tahan karat yang dilengkapi dengan elemen listrik pada suhu $750^{\circ} \mathrm{C}$ dengan lama waktu aktivasi 30, 60 dan 90 menit. Bahan pengaktif yang digunakan adalah larutan asam fosfat $\left(\mathrm{H}_{3} \mathrm{PO}_{4}\right)$ dengan konsentrasi 0,$0 ; 5,0 ; 10,0$ dan $15 \%$.

Hasil penelitian menunjukkan bahwa kondisi optimum untuk membuat arang aktif dengan kualitas terbaik dihasilkan dari arang yang direndam asam fosfat $10 \%$, dengan lama waktu aktivasi 60 menit, menghasilkan rendemen sebesar $98,20 \%$, kadar air 8,39\%, kadar abu $26,70 \%$, kadar zat terbang $8,72 \%$, kadar karbon terikat $64,60 \%$, daya serap terhadap yodium $513 \mathrm{mg} / \mathrm{g}$ dan daya serap terhadap benzena sebesar $16,10 \%$. Arang aktif dari kulit kayu mangium ini hanya dapat digunakan untuk penjernihan air.
\end{abstract}

Kata kunci : Acacia mangium, kulit kayu, arang aktif, karbon terikat, yodium.

\footnotetext{
${ }^{1)}$ Peneliti pada Pusat Penelitian dan Pengembangan Hasil Hutan, Bogor
} 


\section{PENDAHULUAN}

Pohon Acacia mangium Willd. merupakan salah satu jenis pohon Hutan Tanaman Industri (HTI) yang berhasil dikembangkan dibandingkan dengan jenis pohon HTI lainnya, baik ditinjau dari aspek penanaman maupun pemakaian kayunya. Hal ini dimungkinkan mengingat kayu mangium ini dipakai sebagai pemasok utama industri pulp, kertas dan medium density fiber (MDF) yang tidak terlalu mempersyaratkan umur pohon, karena pada umur 7 tahun sudah bisa dipanen. Dalam industri pulp, dan kertas bahan baku kayu yang tidak digunakan dan tersisa adalah kulit kayu. Diperkirakan terdapat $1.665 .150 \mathrm{~m}^{3}$ limbah kulit kayu dengan rendemen kulit antara 12 - 17\% (Pari et al., 2000). Informasi yang dioperoleh dari PT. Musi Hutan Persada (MHP), potensi limbah kulit kayu mangium sebanyak 15,18 ton yang belum dimanfaatkan. Selama ini kulit kayu mangium baru digunakan sebagai sumber energi untuk memanaskan boiler dan perekat tanin. Produk lainnya yang dapat dibuat dari kulit Acacia mangium adalah arang aktif, yang sampai saat ini bahan baku utama untuk membuat arang aktif adalah tempurung kelapa.

Proses pembuatan arang aktif pada prinsipnya dapat dilakukan dengan dua cara yaitu cara kimia dan fisika. Bahan kimia yang umum digunakan sebagai bahan pengaktif adalah $\mathrm{CaCl}_{2}, \mathrm{MgCl}_{2}, \mathrm{ZnCl}_{2}, \mathrm{KCl}, \mathrm{NaCl}$ dan $\mathrm{H}_{3} \mathrm{PO}_{4}$. Sedangkan bahan pengaktif yang digunakan secara fisika adalah uap air, gas $\mathrm{CO}_{2}, \mathrm{~N}_{2}$, dan $\mathrm{O}_{2}$ (Guerrero, 1970). Bahan $\mathrm{NH}_{4} \mathrm{HCO}_{3}$ telah digunakan dalam penelitian terdahulu untuk membuat arang aktif dari kulit kayu mangium sebagai bahan pengaktif pada suhu $900^{\circ} \mathrm{C}$. Hasilnya menunjukkan bahwa arang aktif dari kulit kayu mangium dapat digunakan untuk memurnikan minyak kelapa sawit (Pari, 2000). Dalam penelitian ini pembuatan arang aktif dilakukan dengan cara kombinasi kimia dan fisika yaitu dengan menggunakan $\mathrm{H}_{3} \mathrm{PO}_{4}$ dan uap $\mathrm{H}_{2} \mathrm{O}$ pada suhu $750^{\circ} \mathrm{C}$ dengan tujuan untuk mengetahui pengaruh lama waktu aktivasi dan konsentrasi $\mathrm{H}_{3} \mathrm{PO}_{4}$ terhadap mutu arang aktif yang dihasilkan.

\section{BAHAN DAN METODA}

\section{A. Bahan dan Alat}

Bahan yang digunakan dalam penelitian ini adalah kulit kayu Acacia mangium Willd. Bahan kimia yang digunakan di antaranya adalah asam fosfat, kalium yodida, yodium, natrium tio sulfat, benzena digunakan untuk menentukan kualitas arang aktif dalam hal ini daya serap terhadap larutan dan gas. Peralatan yang digunakan di antaranya adalah retort, desikator, oven dan tanur untuk menentukan kadar air, abu, karbon terikat dan zat terbang.

\section{B. Metode Penelitian}

\section{Pembuatan arang dari kulit kayu mangium}

Kulit kayu mangium diarangkan dalam kiln drum (Gambar 1). yang terbuat dari drum bekas pakai (volume 200 liter). Kiln drum modifikasi terdiri dari empat bagian yaitu badan drum yang dibuka salah satu ujungnya, tutup kiln atas, cerobong dan lubang udara pada bagian bawah drum, lubang udara pada bagian bawah drum juga berfungsi sebagai tempat 
pembakaran pertama. Kulit kayu mangium dipotong-potong kecil, lalu dimasukan ke dalam kiln drum, selanjutnya dinyalakan dengan cara membakarnya melalui bagian lubang udara dengan bantuan umpan ranting kayu $( \pm 2,5 \mathrm{~kg})$. Sesudah bahan baku menyala dan diperkirakan tidak akan padam, maka lubang udara kiln ditutup dan cerobong asap dipasang. Pengarangan dianggap selesai apabila asap yang keluar dari cerobong menipis dan berwarna kebiru-biruan, selanjutnya kiln didinginkan selama 24 jam.

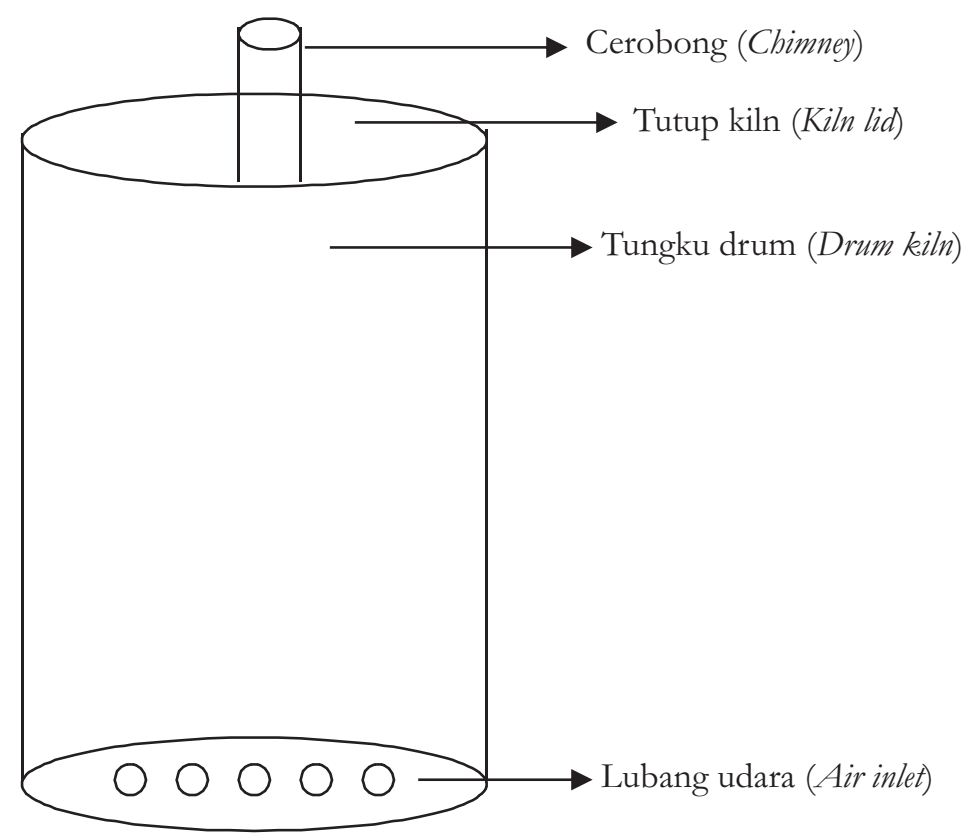

Gambar 1. Tungku arang dari drum minyak yang dimodifikasi

Figure 1. Charcoal kiln from modification of drum oil

\section{Pembuatan arang aktif}

Arang dari kulit kayu mangium dalam bentuk granular direndam dalam larutan $\mathrm{H}_{3} \mathrm{PO}_{4}$ dengan konsentrasi 0 , 5, 10 dan $15 \%$ selama 24 jam, setelah ditiriskan selama satu hari, selanjutnya dimasukan ke dalam retort dengan kapasitas 0,5 kg (Gambar 2) dan dipanaskan pada suhu $750^{\circ} \mathrm{C}$. Setelah suhu retor tercapai, dialirkan dari uap $\mathrm{H}_{2} \mathrm{O}$ selama 30, 60 dan 90 menit. 


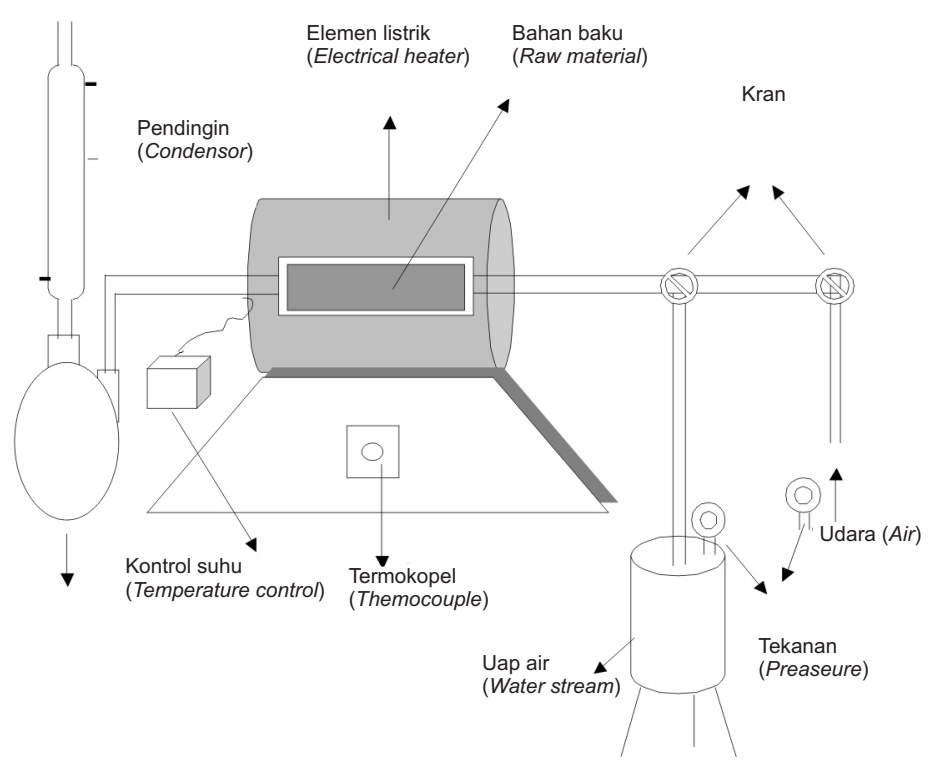

Gambar 2. Tanur aktivasi arang aktif

Figure 2. Activation retort of activated charcoal

\section{Pengujian kualitas arang dan arang aktif}

Kualitas arang yang dihasilkan di uji kualitasnya berdasarkan Standar ASTM (Anonim, 1982) yang meliputi penetapan kadar air, zat terbang, abu, dan kadar karbon terikat. Sedangkan kualitas arang aktif di uji berdasarkan standar Indonesia (Anonim, 1995) yang meliputi penetapan kadar air, abu, zat terbang, karbon, daya serap terhadap yodium dan benzena. Untuk mengetahui pengaruh perlakuan waktu aktivasi dan konsentrasi $\mathrm{H}_{3} \mathrm{PO}_{4}$ terhadap mutu arang aktif yang dihasilkan, dilakukan perhitungan sidik ragam yang dilanjutkan dengan uji regresi dan uji beda nyata jujur (Sudjana, 1980).

\section{HASIL DAN PEMBAHASAN}

\section{A. Arang Kulit Kayu Mangium}

Arang kulit kayu mangium yang digunakan dalam penelitian ini memiliki sifat sebagai berikut: kadar karbon terikat 70,40\%, kadar air 5,99\%, kadar abu 12,50\%, kadar zat terbang $17,20 \%$ dan rendemen sebesar $42,10 \%$. Arang yang dihasilkan memenuhi syarat untuk dapat dijadikan arang aktif karena kadar karbon terikatnya sebesar 70,40\%. Berdasarkan persyaratan Smisek dan Cerny (1970) yaitu sebesar 70\%. Besarnya kadar karbon ini akan berpengaruh positip pada rendemen dan mutu arang aktif. Khusus untuk kadar abu (Smisek dan Cerny, 1970) mensyaratkan sebesar 1-2\% sedangkan FAO menpersyaratkan kadar abu sebesar 4\% (Anonim, 1985), sehingga dalam hal ini kadar abu yang dihasilkan belum memenuhi syarat. Besarnya kadar abu ini mungkin disebabkan terjadinya oksidasi karbon 
lebih lanjut. Untuk hal itu dilakukan pengayakan untuk menghilangkan abu yang menempel pada permukaan arang dan dalam pembuatan arang aktifnya digunakan proses pirolisis lambat (slow pyrolysis). Beberapa hasil penelitian menunjukkan bahwa, walaupun kadar abu arangnya tidak memenuhi persyaratan namun tetap dapat dibuat arang aktif (Komarayati, et al., 1998 dan Pari, 1999) dengan sifat dan mutu arang aktif yang memenuhi standar Indonesia (SNI, 1995).

\section{B. Sifat Arang Aktif}

Sifat arang aktif yang dihasilkan dapat dilihat pada Tabel 1.

\section{Tabel 1. Sifat kimia arang aktif kulit kayu mangium}

Table 1. The chemical properties of mangium wood bark activated charcoal

\begin{tabular}{|c|c|c|c|c|c|c|c|c|}
\hline \multirow{2}{*}{$\begin{array}{c}\text { Waktu aktivasi } \\
\text { Activation times) } \\
\text { minutes }\end{array}$} & \multicolumn{7}{|c|}{ Sifat kimia arang aktif (Chemical properties of activated charcoal) } \\
\cline { 2 - 9 } & $\begin{array}{c}\mathrm{H}_{3} \mathrm{PO}_{4} \\
\%\end{array}$ & $\mathrm{~A}$ & $\mathrm{~B}$ & $\mathrm{C}$ & $\mathrm{D}$ & $\mathrm{E}$ & $\mathrm{F}$ & $\mathrm{G}$ \\
\hline 30 & 0,0 & 73,40 & 12,50 & 12,30 & 8,90 & 78,80 & 11,10 & 369 \\
& 5,0 & 85,60 & 8,63 & 13,20 & 7,03 & 79,70 & 9,98 & 373 \\
& 10,0 & 99,40 & 10,60 & 26,60 & 7,45 & 65,90 & 12,00 & 433 \\
& 15,0 & 91,00 & 12,20 & 32,70 & 10,80 & 56,60 & 15,20 & 511 \\
\hline 60 & 0,0 & 72,50 & 9,30 & 14,10 & 11,70 & 74,10 & 13,20 & 446 \\
& 5,0 & 82,00 & 11,20 & 16,30 & 7,02 & 76,30 & 9,54 & 475 \\
& 10,0 & 98,20 & 8,39 & 26,70 & 8,72 & 64,60 & 16,10 & 513 \\
& 15,0 & 93,50 & 12,90 & 32,70 & 9,06 & 54,60 & 13,10 & 414 \\
\hline 90 & 0,0 & 67,40 & 10,50 & 14,90 & 9,40 & 75,70 & 14,00 & 607 \\
& 5,0 & 80,20 & 11,20 & 15,50 & 7,78 & 77,00 & 9,22 & 392 \\
& 10,0 & 89,00 & 15,20 & 29,40 & 6,08 & 64,50 & 16,20 & 468 \\
& 15,0 & 86,30 & 15,90 & 31,60 & 11,30 & 56,80 & 13,20 & 432 \\
\hline SNI & - & - & 15,00 & 10,00 & 25,00 & 65,00 & 65,00 & 65,00 \\
\hline Arang aktif & & & 20,87 & 5,17 & 48,67 & 46,16 & 2,78 & 643 \\
komersial & & & & & & & & \\
(Commercial & & & & & & & & \\
activated chorcoal) & & & & & & & & \\
\hline
\end{tabular}

Keterangan (Remarks) : A = Rendemen (Yield), \%; B = Kadar air (Moisture content), \%; C = Kadar abu (Ash content), \%; D = Kadar zat terbang (Volatile matter), \%; E = Kadar karbon terikat (Fixed carbon), $\% ; \mathrm{F}=$ Daya serap yodium (Adsorptive capacity of iodine), $\mathrm{mg} / \mathrm{g}$ dan $\mathrm{G}=$ Daya serap benzena (Adsorptive capacity of benzene), $\%$

\section{Rendemen arang aktif}

Rendemen arang aktif yang dihasilkan berkisar antara 67,40 - 99,40\% (Tabel 1). Berdasarkan perhitungan sidik ragam ternyata semua perlakuan dan interaksinya sangat berpengaruh terhadap rendemen yang dihasilkan (Tabel 2). Rendemen tertinggi (99,40\%) dihasilkan oleh arang kulit kayu mangium yang direndam $\mathrm{H}_{3} \mathrm{PO}_{4} 10 \%$ dengan lama waktu aktivasi 30 menit dan rendemen yang terendah (67,40\%) dihasilkan oleh arang kulit kayu mangium yang tidak direndam $\mathrm{H}_{3} \mathrm{PO}_{4}$ dengan lama waktu aktivasi 90 menit. Sidik regresi 
menunjukkan bahwa semakin lama waktu aktivasi rendemen arang aktif yang dihasilkan cenderung turun (Tabel 3). Rendahnya rendemen ini menunjukkan bahwa reaksi antara atom $\mathrm{C}$ dengan uap $\mathrm{H}_{2} \mathrm{O}$ makin banyak sesuai dengan mekanisme reaksi kimia menurut (Walker, 1996) di bawah ini:

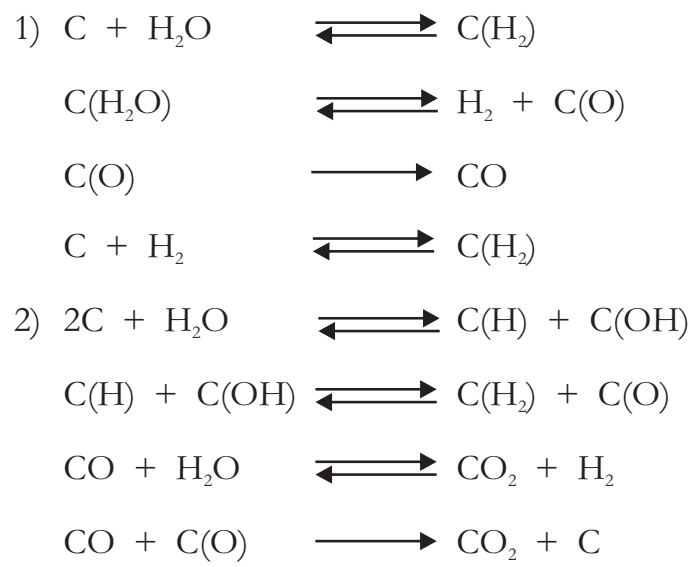

Sebaliknya, walaupun berdasarkan perhitungan sidik regresi tidak nyata (Tabel 3) namun menunjukkan bahwa makin tinggi konsentrasi $\mathrm{H}_{3} \mathrm{PO}_{4}$, rendemen arang aktif yang dihasilkan cenderung naik. Hal ini menunjukkan terjadi reaksi antara $\mathrm{H}_{3} \mathrm{PO}_{4}$ dengan gugus $\mathrm{OH}$ yang terdapat dalam bahan sehingga tidak terjadi proses oksidasi lebih lanjut (Yue, et al., 2003).

Hasil uji BNJ menunjukkan bahwa tidak semua perlakuan dan interaksinya menyebabkan perbedaan rendemen arang aktif yang nyata (Tabel 6). Sebagai contoh adalah arang yang diaktivasi selama 30 menit dan direndam dalam $\mathrm{H}_{3} \mathrm{PO}_{4} 10 \%$ (a1b3) sebesar 99,4\% tidak memberikan pebedaan yang nyata dibandingkan dengan arang yang diaktivasi selama 60 menit dan direndam dalam $\mathrm{H}_{3} \mathrm{PO}_{4} 10 \%$ (a2b3) sebesar 98,2\%.

\section{Kadar air}

Kadar air arang aktif yang dihasilkan berkisar antara 8,39 - 15,90\% (Tabel 1). Kadar air arang aktif yang dihasilkan ini semuanya memenuhi syarat standar Indonesia (SNI, 1995) kecuali arang aktif yang direndam $\mathrm{H}_{3} \mathrm{PO}_{4} 15 \%$ dengan lama aktivasi 90 menit karena kadarnya lebih dari $15 \%$. Berdasarkan perhitungan sidik ragam ternyata semua perlakuan dan interaksinya sangat berpengaruh terhadap kadar air yang dihasilkan (Tabel 2). Kadar air tertinggi $(15,90 \%)$ dihasilkan oleh arang kulit kayu mangium yang direndam $\mathrm{H}_{3} \mathrm{PO}_{4} 15 \%$ dengan lama waktu aktivasi 90 menit dan kadar air yang terendah (8,39\%) dihasilkan oleh arang kulit kayu mangium yang direndam $\mathrm{H}_{3} \mathrm{PO}_{4} 10 \%$ dengan lama waktu aktivasi 60 menit. Dari uji regresi ternyata makin lama waktu aktivasi dan makin tinggi konsentrasi $\mathrm{H}_{3} \mathrm{PO}_{4}$, kadar air yang dihasilkan cenderung meningkat (Tabel 3 dan 4). Besarnya kadar air ini selain disebabkan terjadinya peningkatan sifat higroskopis arang aktif terhadap uap air, juga disebabkan terjadinya pengikatan molekul air oleh 6 atom karbon yang telah diaktivasi (Pari, et 
al., 1996). Apabila hasil ini dibandingkan dengan arang aktif komersial sebesar 20,87\%, maka kadar air hasil penelitian masih lebih rendah.

Hasil uji BNJ menunjukkan bahwa tidak semua perlakuan dan interaksinya menyebabkan perbedaan kadar air yang nyata (Tabel 6). Sebagai contoh adalah arang yang diaktivasi dengan lama waktu 60 menit dan direndam pada $\mathrm{H}_{3} \mathrm{PO}_{4} 5 \%$ (a2b2) sebesar 11,20\% tidak menghasilkan perbedaan yang nyata dibandingkan dengan arang yang diaktivasi selama 30 menit dan direndam pada $\mathrm{H}_{3} \mathrm{PO}_{4} 10 \%$ (a1b3) sebesar 10,60\%.

Table 2. Ringkasan sidik ragam sifat arang aktif dari kulit kayu mangium Table 2. Summarized analysis of variance on properties of mangium bark activated charcoal

\begin{tabular}{|c|c|c|c|c|}
\hline No & Sifat (Properties) & $\begin{array}{l}\text { Perlakuan } \\
\text { (Treatment) }\end{array}$ & $\begin{array}{l}\text { Kuadrat tengah } \\
\text { (Mean square) }\end{array}$ & $\begin{array}{c}\text { F-hitung } \\
\text { (F-calculated })\end{array}$ \\
\hline 1 & Rendemen (Yield), $\%$ & $\begin{array}{c}\mathrm{A} \\
\mathrm{B} \\
\mathrm{AB}\end{array}$ & $\begin{array}{c}104,61 \\
432,81 \\
7,64\end{array}$ & $\begin{array}{c}67,01 * * \\
432,81^{* *} \\
4,89 * *\end{array}$ \\
\hline 2 & Kadar air (Moisture content), $\%$ & $\begin{array}{c}\mathrm{A} \\
\mathrm{B} \\
\mathrm{AB}\end{array}$ & $\begin{array}{l}17,09 \\
13,15 \\
20,41\end{array}$ & $\begin{array}{l}13,74^{* *} \\
10,60^{* *} \\
16,45^{* *}\end{array}$ \\
\hline 3 & Kadar abu (Ash content), $\%$ & $\begin{array}{c}\mathrm{A} \\
\mathrm{B} \\
\mathrm{AB}\end{array}$ & $\begin{array}{c}5,92 \\
508,80 \\
173,51\end{array}$ & $\begin{array}{c}0,065 \\
0,5602 \\
0,1910\end{array}$ \\
\hline 4 & $\begin{array}{l}\text { Kadar zat terbang } \\
\text { (Volatile matter), } \%\end{array}$ & $\begin{array}{c}\mathrm{A} \\
\mathrm{B} \\
\mathrm{AB}\end{array}$ & $\begin{array}{c}0,91 \\
14,28 \\
1,17 \\
\end{array}$ & $\begin{array}{c}0,3192 \\
5,0128^{* *} \\
0,4116\end{array}$ \\
\hline 5 & $\begin{array}{l}\text { Kadar karbon terikat } \\
\text { (Fixed carbon), \% }\end{array}$ & $\begin{array}{c}\mathrm{A} \\
\mathrm{B} \\
\mathrm{AB}\end{array}$ & $\begin{array}{c}16,52 \\
623,26 \\
1,84\end{array}$ & $\begin{array}{l}0,0570 \\
2,1611 \\
0,0063\end{array}$ \\
\hline 6 & $\begin{array}{l}\text { Daya serap yodium } \\
\text { (Adsorptive capacity of iodine), } \mathrm{mg} / \mathrm{g}\end{array}$ & $\begin{array}{c}\mathrm{A} \\
\mathrm{B} \\
\mathrm{AB}\end{array}$ & $\begin{array}{c}6184,5 \\
4701,5 \\
12579,8\end{array}$ & $\begin{array}{l}21,31 * * \\
16,29 * * \\
43,60 * *\end{array}$ \\
\hline 7 & $\begin{array}{l}\text { Daya serap benzena } \\
\text { (Adsorptive capacity of benzene), } \%\end{array}$ & $\begin{array}{c}\mathrm{A} \\
\mathrm{B} \\
\mathrm{AB}\end{array}$ & $\begin{array}{c}2,72 \\
30,58 \\
5,45\end{array}$ & $\begin{array}{c}5,54^{*} \\
62,41^{* *} \\
11,12^{* *}\end{array}$ \\
\hline
\end{tabular}

Keterangan $($ Remarks $): \mathrm{A}=$ Perlakuan waktu aktivasi $($ Activation time treatment $), \mathrm{B}=$ Konsentrasi $\mathrm{H}_{3} \mathrm{PO}_{4}$ (Concentration of $\left.\mathrm{H}_{3} \mathrm{PO}_{4}\right), \mathrm{AB}=$ Interaksi (Interaction), ${ }^{* *}=$ Sangat nyata $($ Highly significant $),{ }^{*}=$ Nyata (Significant) 


\section{Kadar abu}

Kadar abu arang aktif yang dihasilkan berkisar antara 12,30 - 32,70\% (Tabel 1). Nilai kadar abu yang dihasilkan semuanya belum memenuhi syarat standar Indonesia (SNI, 1995) karena masih lebih dari 10\%. Berdasarkan perhitungan sidik ragam ternyata semua perlakuan dan interaksinya tidak ada yang berpengaruh terhadap kadar abu yang dihasilkan (Tabel 2). Kadar abu tertinggi (32,70\%) dihasilkan oleh arang kulit kayu mangium yang direndam $\mathrm{H}_{3} \mathrm{PO}_{4} 15 \%$ dengan lama waktu aktivasi 60 menit dan kadar abu yang terendah $(12,30 \%)$ dihasilkan oleh arang yang tidak direndam $\mathrm{H}_{3} \mathrm{PO}_{4}$ dengan lama waktu aktivasi 30 menit. Tingginya kadar abu yang dihasilkan dapat mengurangi daya adsorpsi arang aktif, karena pori arang aktif terisi oleh mineral-mineral logam seperti magnesium, kalsium, kalium (Smisek dan Cerny, 1970). Walaupun berdasarkan uji sidik ragam tidak nyata, namun berdasarkan hasil perhitungan sidik regresi menunjukkan bahwa makin lama waktu aktivasi dan makin tinggi konsentrasi $\mathrm{H}_{3} \mathrm{PO}_{4}$, kadar abu arang aktif yang dihasilkan meningkat (Tabel 3 dan 4). Peningkatan kadar abu ini menunjukkan adanya proses oksidasi lebih lanjut terutama dari partikel halus. Apabila hasil ini dibandingkan dengan arang aktif komersial sebesar 5,17\%, maka kadar abu hasil penelitian lebih tinggi. Namun demikian apabila dibandingkan dengan hasil penelitian Pari (2000), maka kadar abunya tidak jauh berbeda antara 11,81 - 16,90\%.

\section{Kadat zat terbang}

Kadar zat terbang arang aktif yang dihasilkan berkisar antara 6,08 - 11,70\% (Tabel 1). Nilai kadar zat terbang yang dihasilkan ini semuanya memenuhi syarat standar Indonesia (SNI, 1995) karena kadarnya tidak lebih dari 25\%. Berdasarkan perhitungan sidik ragam ternyata hanya perlakuan konsentrasi bahan pengaktif yang berpengaruh terhadap kadar zat terbang arang aktif yang dihasilkan (Tabel 2). Kadar zat terbang tertinggi (11,70\%) dihasilkan oleh arang kulit kayu mangium yang tidak direndam $\mathrm{H}_{3} \mathrm{PO}_{4}$ dengan lama waktu aktivasi 60 menit dan kadar zat terbang yang terendah (6,08\%) dihasilkan oleh arang kulit kayu mangium yang direndam $\mathrm{H}_{3} \mathrm{PO}_{4} 10 \%$ dengan lama waktu aktivasi 90 menit. Tinggi rendahnya kadar zat terbang yang dihasilkan menunjukkan bahwa permukaan arang aktif masih ditutupi oleh senyawa non karbon sehingga mempengaruhi kemampuan daya serapnya. Apabila hasil ini dibandingkan dengan arang aktif komersial sebesar 48,67\%, maka kadar zat terbang hasil penelitian masih lebih rendah.

Hasil uji BNJ menunjukkan bahwa tidak semua perlakuan konsentrasi bahan pengaktif memberikan perbedaan yang nyata terhadap kadar zat terbang arang aktif (Tabel 6). Sebagai contoh adalah arang yang direndam $\mathrm{H}_{3} \mathrm{PO}_{4}$ 5\% (b2) sebesar 7,27\% tidak memberikan perbedaan kadar zat terbang yang nyata dibandingkan dengan arang yang direndam H3PO4 $10 \%$ (b3) sebesar $7,41 \%$

\section{Kadar karbon terikat}

Kadar karbon terikat arang aktif yang dihasilkan berkisar antara 54,60 - 79,70\% (Tabel 1). Kadar karbon terikat yang tidak memenuhi syarat standar Indonesia (SNI, 1995) karena kadarnya kurang dari 65\% adalah: (1) arang yang direndam $\mathrm{H}_{3} \mathrm{PO}_{4} 10 \%$ dengan lama waktu aktivasi 60 dan 90 menit, (2) arang yang direndam $\mathrm{H}_{3} \mathrm{PO}_{4}$ 15\% dengan lama waktu aktivasi 30, 60 dan 90 menit. Berdasarkan perhitungan sidik ragam ternyata semua perlakuan dan 
interaksinya tidak ada yang berpengaruh terhadap kadar karbon terikat yang dihasilkan (Tabel 2). Kadar karbon terikat tertinggi (79,70\%) dihasilkan oleh arang kulit kayu mangium yang direndam $\mathrm{H}_{3} \mathrm{PO}_{4} 5 \%$ dengan lama waktu aktivasi 30 menit dan kadar karbon terikat yang terendah $(54,60 \%)$ dihasilkan oleh arang kulit kayu mangium yang direndam $\mathrm{H}_{3} \mathrm{PO}_{4} 15 \%$ dengan lama waktu aktivasi 60 menit. Tinggi rendahnya kadar karbon terikat yang dihasilkan selain dipengaruhi oleh tinggi rendahnya kadar abu dan zat terbang juga dipengaruhi oleh kandungan selulosa dan lignin yang dapat dikonversi menjadi atom karbon (Pari, 2004). Apabila hasil ini dibandingkan dengan arang aktif komersial sebesar 46,16\%, maka kadar karbon hasil penelitian masih lebih rendah. Walaupun berdasarkan uji sidik ragam tidak nyata, namun berdasarkan hasil perhitungan sidik regresi terlihat bahwa makin lama waktu aktivasi dan makin tinggi konsentrasi asam fosfat, kadar karbon terikat arang aktif yang dihasilkan makin rendah (Tabel 3 dan 4). Rendahnya kadar karbon ini menunjukkan banyak atom karbon yang bereaksi dengan uap air menghasilkan gas $\mathrm{CO}$ dan $\mathrm{CO}_{2}$ sehingga atom karbon yang tertata kembali membentuk struktur heksagonal sedikit.

\section{Daya serap arang aktif terhadap yodium}

Daya serap arang aktif terhadap yodium berkisar antara $369 \mathrm{mg} / \mathrm{g}-607 \mathrm{mg} / \mathrm{g}$ (Tabel 1). Daya serap arang aktif yang memenuhi syarat standar Amerika yang khusus untuk aplikasi penjernihan air (Anonim, 1978) adalah arang yang direndam $\mathrm{H}_{3} \mathrm{PO}_{4} 15 \%$ dan $10 \%$, serta yang tidak direndam dengan lama waktu aktivasi 30 dan 60 serta 90 menit karena daya serapnya lebih dari $500 \mathrm{mg} / \mathrm{g}$. Namun demikian apabila besarnya daya serap ini di nilai berdasarkan standar Indonesia (SNI, 1995) semuanya tidak ada yang memenuhi syarat karena kurang dari $750 \mathrm{mg} / \mathrm{g}$. Berdasarkan perhitungan sidik ragam ternyata semua perlakuan dan interaksinya berpengaruh nyata terhadap daya serap yang dihasilkan (Tabel 2). Daya serap yodium tertinggi $(607 \mathrm{mg} / \mathrm{g})$ dihasilkan oleh arang kulit kayu mangium yang tidak direndam $\mathrm{H}_{3} \mathrm{PO}_{4}$ dengan lama waktu aktivasi 90 menit dan daya serap terendah $(369 \mathrm{mg} / \mathrm{g})$ dihasilkan oleh arang kulit kayu mangium yang tidak direndam $\mathrm{H}_{3} \mathrm{PO}_{4}$ dengan lama waktu aktivasi 30 menit. Tinggi rendahnya daya serap arang aktif terhadap yodium ini menunjukkan diameter pori arang aktif yang berukuran 10 Angstrom banyak. Apabila hasil ini dibandingkan dengan arang aktif komersial sebesar 643,04 mg/g, maka daya serap hasil penelitian tidak jauh berbeda. Namun demikian terdapat perbedaan yang nyata apabila dibandingkan dengan hasil penelitian Pari (2000) yang menyimpulkan daya serap terhadap yodium antara 667,16 - 866,23 $\mathrm{mg} / \mathrm{g}$. Perbedaan ini lebih disebabkan oleh suhu aktivasi yang berbeda yaitu $900^{\circ} \mathrm{C}$. Dari uji regresi terlihat bahwa makin lama waktu aktivasi, daya serap arang aktif terhadap yodium yang dihasilkan cenderung meningkat (Tabel 3). Peningkatan daya serap ini memperlihatkan bahwa atom karbon yang membentuk kristalit heksagonal makin banyak sehingga celah atau pori yang terbentuk di antara lapisan kristalit juga makin besar. Hasil ini sesuai dengan Yue, et al. (2003) yang menyimpulkan bahwa adanya senyawa $\mathrm{P}_{2} \mathrm{O}_{5}$ hasil dekomposisi $\mathrm{H}_{3} \mathrm{PO}_{4}$ yang terperangkap di dalam arang akan menimbulkan struktur mikropori dan mesopori pada struktur bagian dalam. Selain itu semakin tinggi konsentrasi $\mathrm{H}_{3} \mathrm{PO}_{4}$ juga menghasilkan struktur mesopori yang mempunyai luas permukaan dan volume pori yang besar (Baquero, et al., 2003).

Hasil uji BNJ menunjukkan bahwa tidak semua perlakuan dan interaksinya menyebabkan perbedaan daya serap arang aktif terhadap yodium yang nyata (Tabel 6). 
Sebagai contoh arang yang diaktivasi dengan lama waktu aktivasi 60 menit dan direndam pada $\mathrm{H}_{3} \mathrm{PO}_{4} \%$ (a2b2) sebesar $475 \mathrm{mg} / \mathrm{g}$ tidak memberikan perbedaan kadar karbon yang nyata dibandingkan dengan arang yang diaktivasi selama 90 menit dan direndam pada $\mathrm{H}_{3} \mathrm{PO}_{4} 10 \%$ (a3b3) sebesar $468 \mathrm{mg} / \mathrm{g}$.

\section{Daya serap arang aktif terhadap benzena}

Daya serap arang aktif terhadap benzena berkisar antara 9,22 - 16,2\% (Tabel 1). Daya serap arang aktif terhadap benzena yang dihasilkan ini belum memenuhi syarat standar Indonesia (SNI, 1995) karena masih kurang dari 25\%. Berdasarkan perhitungan sidik ragam ternyata semua perlakuan dan interaksinya berpengaruh nyata terhadap daya serap yang dihasilkan (Tabel 2). Daya serap benzena terendah (9,22\%) dihasilkan oleh arang kulit kayu mangium yang direndam $\mathrm{H}_{3} \mathrm{PO}_{4}$ \% dengan lama waktu aktivasi 90 menit dan daya serap tertinggi (16,20\%) dihasilkan oleh arang kulit kayu mangium yang direndam $\mathrm{H}_{3} \mathrm{PO}_{4} 10 \%$ dengan lama waktu aktivasi 90 menit. Besarnya daya serap arang aktif terhadap benzena ini mencerminkan permukaan arang aktif lebih bersifat non polar sehingga dapat digunakan untuk menyerap polutan yang juga bersifat non polar seperti karbon tetra klorida. Apabila hasil ini dibandingkan dengan arang aktif komersial sebesar 2,78\%, maka daya serap benzena hasil penelitian masih lebih tinggi. Dari uji regresi terlihat bahwa makin lama waktu aktivasi, daya serap arang aktif terhadap benzena yang dihasilkan meningkat (Tabel 3). Peningkatan daya serap ini memperlihatkan permukaan arang aktif lebih bersifat non polar.

Hasil uji BNJ menunjukkan bahwa tidak semua perlakuan dan interaksinya menyebabkan perbedaan yang nyata daya serap arang aktif terhadap benzena (Tabel 6). Sebagai contoh adalah arang yang diaktivasi dengan selama 30 menit dan direndam pada $\mathrm{H}_{3} \mathrm{PO}_{4} 5 \%$ (a1b2) sebesar 9,98\% tidak memberikan perbedaan daya serap yang berbeda dibandingkan dengan arang yang diaktivasi selama 60 menit dan direndam pada $\mathrm{H}_{3} \mathrm{PO}_{4} 5 \%$ (a2b2) sebesar $9,54 \%$. 
Table 3. Persamaan regresi hubungan antara lama waktu aktivasi (X1) terhadap sifat arang aktif (Y)

Table 3. Regressions between activation time (X1) on activated charcoal properties $(Y)$

\begin{tabular}{|l|c|c|c|}
\hline \multicolumn{1}{|c|}{$\begin{array}{c}\text { Sifat } \\
\text { (Properties) }\end{array}$} & \multicolumn{1}{|c|}{$\begin{array}{c}\text { Regresi } \\
\text { (Regression) }\end{array}$} & $\begin{array}{c}\text { Koefisien korelasi } \\
\text { (Coeficient orrelation) })\end{array}$ & $\begin{array}{c}\text { F-hitung } \\
(\text { F-calc })\end{array}$ \\
\hline $\begin{array}{l}\text { Rendemen (Yield), \% } \\
\text { Kadar air (Moisture content), \% }\end{array}$ & $\mathrm{Y}=91,50-0,11 \mathrm{X} 1$ & $-0,9159$ & $5,1873^{*}$ \\
Kadar abu (Ash content) \% & $\mathrm{Y}=9,32+0,04 \mathrm{X} 1$ & 0,7588 & 1,3623 \\
$\begin{array}{l}\text { Kadar zat terbang } \\
\text { (Volatile matter), \% }\end{array}$ & $\mathrm{Y}=8,69+0,002 \mathrm{X} 1$ & 0,9585 & $11,3103^{* *}$ \\
$\begin{array}{l}\text { Kadar karbon terikat } \\
\text { (Fixed carbon), \% }\end{array}$ & $\mathrm{Y}=70,47-0,03 \mathrm{X} 1$ & $-0,6087$ & 0,0177 \\
$\begin{array}{l}\text { Daya serap yodium } \\
\text { (Adsorptive capacity of } \\
\text { iodine), mg/g }\end{array}$ & $\mathrm{Y}=399,5+0,88 \mathrm{X} 1$ & 0,9573 & $10,9770^{* *}$ \\
$\begin{array}{l}\text { Daya serap benzena } \\
\text { (Adsorptive capacity of } \\
\text { benzene), \% }\end{array}$ & $\mathrm{Y}=11,65+0,02 \mathrm{X} 1$ & 0,9298 & $6,3947 * *$ \\
\hline
\end{tabular}

Keterangan (Remarks): ** = Sangat nyata (Highly significant); * = Nyata (Significant)

Table 4. Persamaan regresi hubungan antara konsentrasi $\mathrm{H}_{3} \mathbf{P O}_{4}(\mathrm{X} 2)$ terhadap sifat arang aktif (Y)

Table 4. Regressions between $\mathrm{H}_{3} \mathrm{PO}_{4}$ concentration (X2) on activated charcoal properties $(Y)$

\begin{tabular}{|l|c|c|c|}
\hline \multicolumn{1}{|c|}{$\begin{array}{c}\text { Sifat } \\
\text { (Properties) }\end{array}$} & \multicolumn{1}{c|}{$\begin{array}{c}\text { Regresi } \\
\text { (Regression) }\end{array}$} & $\begin{array}{c}\text { Koefisien korelasi } \\
\text { Coeficient orrelation) }\end{array}$ & $\begin{array}{c}\text { F-hitung } \\
(\text { F-calc })\end{array}$ \\
\hline $\begin{array}{l}\text { Rendemen (Yield), \% } \\
\text { Kadar air (Moisture content), \% }\end{array}$ & $\mathrm{Y}=74,31+1,41 \mathrm{X} 2$ & 0,8571 & 2,7673 \\
$\begin{array}{l}\text { Kadar abu (Ash content), \% } \\
\text { Kadar zat terbang } \\
\text { (Volatile matter), \% }\end{array}$ & $\mathrm{Y}=10,08+0,19 \mathrm{X} 2$ & 0,9516 & 2,6405 \\
$\begin{array}{l}\text { Kadar karbon terikat } \\
\text { (Fixed carbon), \% }\end{array}$ & $\mathrm{Y}=8,57+0,025 \mathrm{X} 2$ & 0,9571 & $10,8580^{* *}$ \\
$\begin{array}{l}\text { Daya serap yodium } \\
\text { (Adsorptive capacity of }\end{array}$ & $\mathrm{Y}=79,71-1,46 \mathrm{X} 2$ & $-0,0999$ & 0,0101 \\
iodine), mg/g & $\mathrm{Y}=453,7-0,14 \mathrm{X} 2$ & $-0,0327$ & $0,2054^{* *}$ \\
$\begin{array}{l}\text { Daya serap benzena } \\
\text { (Adsorptive capacity of } \\
\text { benzene), \% }\end{array}$ & $\mathrm{Y}=11,48+0,16 \mathrm{X} 2$ & 0,4761 & 0,2929 \\
\hline
\end{tabular}

Keterangan (Remarks): ** = Sangat nyata (Highly significant) 


\section{Kondisi terbaik pembuatan arang aktif}

Kondisi terbaik didefinisikan sebagai kondisi perlakuan yang dapat memberikan hasil arang aktif terbaik, didasarkan atas rendemen dan daya serap yodium (Hartoyo, et al., 1990). Kondisi optimum untuk membuat arang aktif dari kulit kayu mangium adalah arang yang diaktivasi selama 60 menit dengan konsentrasi $\mathrm{H}_{3} \mathrm{PO}_{4}$ sebesar 10\%. Pada perlakuan ini rendemen yang dihasilkan sebesar $98,20 \%$ dengan daya serap yodium sebesar $513 \mathrm{mg} / \mathrm{g}$. Nilai daya serap yang diperoleh memenuhi syarat Standar Amerika dan dengan nilai sebesar itu maka produk arang aktif yang dihasilkan hanya dapat digunakan untuk menjernihkan air

Tabel 5. Kondisi terbaik pembuatan arang aktif Table 5. The best condition to manufacture activated charcoal

\begin{tabular}{|c|c|c|}
\hline $\begin{array}{c}\text { Waktu aktivasi, menit } \\
\text { (Activation time, minutes) }\end{array}$ & $\begin{array}{c}\mathrm{H}_{3} \mathrm{PO}_{4} \\
\%\end{array}$ & $\begin{array}{c}\text { Kondisi terbaik } \\
\text { (The best condition), } \mathrm{mg} / \mathrm{g}\end{array}$ \\
\hline \multirow{2}{*}{0} & 0 & 270,84 \\
& 5 & 319,88 \\
& 10 & 430,40 \\
& 15 & 465,01 \\
\hline \multirow{2}{*}{60} & 0 & 323,35 \\
& 5 & 389,50 \\
& 10 & 503,76 \\
& 15 & 387,09 \\
\hline \multirow{2}{*}{90} & 0 & 409,12 \\
& 5 & 314,38 \\
& 10 & 335,21 \\
& 15 & 384,89 \\
\hline
\end{tabular}

\section{KESIMPULAN}

Kulit kayu mangium dapat dibuat arang dengan sifat-sifat sebagai berikut: kadar karbon terikat $70,40 \%$, kadar air 5,99\%, kadar abu 12,50\%, kadar zat terbang $17,20 \%$ dan rendemen arang yang dihasilkan sebesar 42,10\%. Arang ini dapat dijadikan arang aktif karena kadar karbon terikatnya memenuhi persyaratan, yaitu lebih dari $70 \%$.

Mutu arang aktif yang terbaik dihasilkan dari arang yang direndam asam fosfat $10 \%$, dengan lama waktu aktivasi 60 menit, menghasilkan rendemen sebesar 98,2\%, kadar air $8,39 \%$, kadar abu $26,70 \%$, kadar zat terbang $8,72 \%$, kadar karbon terikat $64,6 \%$, daya serap terhadap yodium $513 \mathrm{mg} / \mathrm{g}$ dan daya serap terhadap benzena sebesar 16,10\%. Berdasarkan besarnya daya serap terhadap yodium, maka arang aktif dari kulti kayu mangium yang dihasilkan dapat digunakan untuk penjernihan air. 


\section{DAFTAR PUSTAKA}

Anonim. 1985. Industrial charcoal making. Food and Agriculture Organization of The United Nations, Rome.

1995. Arang aktif teknis. Badan Standardisasi Nasional, Jakarta. SNI 06-3730-1995. 1982. Standar methode coal and coke. ASTM, Philadelphia.

1978. Standar methode of water. American Water Works Association, Colorado. B 600-78.

Baquero, M.C., Giraldo, L., Moreno, J.C., Garcia, F.S., Alonso, A.M., and J.M.D. Tascon. 2003. Activated carbons by pyrolysis of coffee bean husks in presence of phosphoric acid. Journal of Analytical and Applied Pyrolysis. (70): 779-784

Buekens, A., Keirsse, H., Schoeters, J. and A. Verbeeck. 1985. Production of activated carbon from Euphorbia tirucalli. Final report. Universiteit Brussel.

Guerrero, A.E. and L.A. Reyes. 1970. Preparation of activated carbon from coconut cor Dust. Coconut research and development. Vol 3. United Coconut Association of The Philppines Inc. Manila.

Hartoyo, Hudaya, dan Fadli. 1990. Pembuatan arang aktif dari tempurung kelapa dan kayu bakau dengan cara aktivasi uap. Jurnal Penelitian Hasil Hutan. 18 (1): 8-16. Pusat Litbang Hasil Hutan. Bogor.

Hassler, J.W. 1974. Purification with activated carbon industrial. Commersial and environmental. Chemical Publishing Co. Inc. New York.

Komarayati, S., Hendra, D dan Gusmailina. 1998. Pembuatan arang aktif dari biomassa hutan. Buletin Penelitian Hasil Hutan. 16 (2): 61-68. Pusat Litbang Hasil Hutan. Bogor.

Pari, G. 1999. Karakterisasi arang aktif dari arang serbuk gergajian sengon dengan bahan pengaktif $\mathrm{NH}_{4} \mathrm{HCO}_{3}$. Buletin Penelitian Hasil Hutan. 17 (2): 89-100. Pusat Litbang Hasil Hutan. Bogor.

Pari, G. 2004. Kajian struktur arang aktif dari serbuk gergaji kayu sebagai adsorben emisi formaldehida kayu lapis. Disertasi. Sekolah Pascasarjana, Insitut Pertanian Bogor. Bogor.

Pari, G., Tjutju, N. dan Hartoyo. 2000. Kemungkinan pemanfaatan arang kulit kayu Acacia mangium Willd. untuk pemurnian minyak kelapa sawit. Buletin Penelitian Hasil Hutan 18 (1) : 40 - 53. Pusat Litbang Teknologi Hasil Hutan. Bogor.

Smisek, M and S. Cerny. 1970. Active carbon: Manufacture, properties and application. Elsevier Publishing Company, New York.

Sudjana. 1980. Disain dan eksperimenat analisis. Tarsito, Bandung.

Walker, P.L. 1996. Production of activated carbons: Use of $\mathrm{CO}_{2}$ versus $\mathrm{H}_{2} \mathrm{O}$ as activating agent. Carbon 34: 1297 - 1299.

Yue, Z., Economy, J., and C.L. Mangun. 2003. Preparation of fibrous porous materials by chemical activation 2. $\mathrm{H}_{3} \mathrm{PO}_{4}$ activation of polymer coated fibers. Carbon 41: 18091817. 
JURNAL Penelitian Hasil Hutan Vol. 24 No. 1, Februari 2006: 33-46

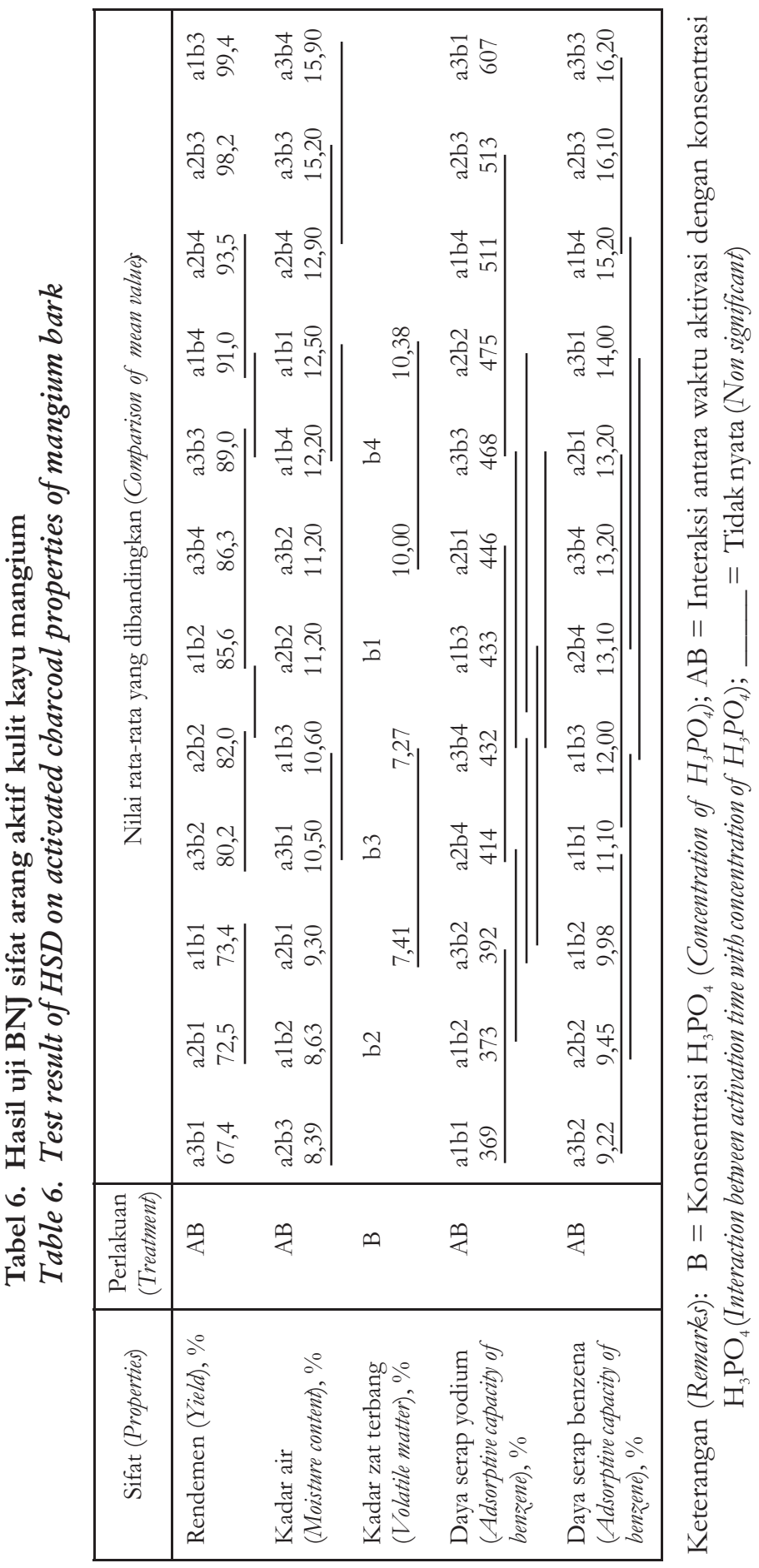

